УДК 37.078256.71

DOI: 10.37026/2520-6427-2021-108-4-146-151
Віталій ЩЕРБИНА,

кандидат педагогічних наук,

доцент кафедри педагогіки, психології

та освітнього менеджменту

імені проф. С. Петухова

Херсонського державного університету,

м. Херсон, Україна

ORCID: 0000-0002-5890-7284,

e-mail: vitaliysherbyna85@gmail.com

Олена ЧАБАН,

кандидат педагогічних наук, дочент,

дочент кафедри теорії та методики

дошкільної і початкової освіти

Херсонського держсавного університету,

м. Херсон, Україна

ORCID: 0000-0001-7494-1223

e-mail:mriya2211@ukr.net

\title{
ФОРМУВАННЯ ЕМОЦИЙНОГО СВІТУ ДИТИНИ В ПЕДАГОГІЧНІЙ ТВОРЧОСТІ ВАСИЛЯ СУХОМЛИНСЬКОГО
}

\begin{abstract}
Анотація. У статті здійснено аналіз проблеми формування емоційного світу дитини в педагогічній творчості Василя Сухомлинського. Схарактеризовано основні прачі педагога ("Серие віддаю дітям», «Павлиська середня школа», «Методика виховання колективу»), в яких викладено та доведено на практиці положення про те, щзо від активності особистості дитини залежить формування їі емоиійного світу. Доведено, що в різні періоди вікового розвитку дитини основою ї̈ розвитку виступає різноманітність видів діяльності (гра, навчання тощьо), від яскравості та насиченості якої залежить формування емочійного світу дитини.

Окреслено, щзо в Павлиші видатним педагогом була розроблена й зреалізована чітка иілеспрямована освітня система, всі складники якої (форми, методи, прийоми, засоби) грунтувалися на народно-педагогічних
\end{abstract}

і гуманістичних засадах, а також мали дитиночентричний характер. Мету окресленої вище системи педагог убачав у формуванні радісного й позитивного ставлення дитини до життя. У зв'язку з иим поряд із традиційними підходами В. Сухомлинський застосовував нові авторські методики, як-от складання казок, етичні бесіди, культуру бажань та ін.

Розкрито творчі ідеї педагога стосовно зв'язку емочійно-вольової складової у формуванні особистості школярів із прагненням до самовиховання. Визначено напрями та засоби актуалізаиії емочійно-вольових передумов становлення особистості дитини як суб 'єкта виховання. Описано можливість урахування виявлених вікових та індивідуальних особливостей особистості школяра як суб'єкта виховання в сучасній школі.

Ключові слова: особистість дитини, емочійний світ, воля, педагогіка Василя Сухомлинського.

\author{
Vitaliy SHCHERBYNA, \\ Candidate of Pedagogical Sciences, \\ Associate Professor of Pedagogy, \\ Psychology and Educational Management, \\ Kherson State University, \\ Kherson, Ukraine \\ ORCID 0000-0002-5890-7284 \\ e-mail:vitaliysherbina85@gmail.com \\ Olena CHABAN, \\ Candidate of Pedagogical Sciences, \\ Associate Professor, \\ Associate Professor of Department Theory \\ and Methodology of Pre-school and Primary Education, \\ Kherson State University, \\ Kherson, Ukraine \\ ORCID: 0000-0001-7494-1223 \\ e-mail:mriya2211@ukr.net
}

\section{FORMATION OF THE EMOTIONAL WORLD OF THE CHILD IN THE PEDAGOGICAL WORKS OF VASYL SUKHOMLYNSKY}

Abstract. The article deals with the problem of formation the child's emotional world in the pedagogical works of Vasyl Sukhomlynsky. The authors identify the main publications of the pedagogue, including "I give my 
heart to children», «Pavlysh secondary school», «Methods of team education». In these publications studied that the activity of the child's personality depends on the formation of his emotional world.

Sukhomlynsky thought that an important condition of the formation of a comprehensively developed personality is its various activities. In different periods of the child's development, the leading aspect is a different type of activity (play or learning) and the the formation of the emotional world of the child depends on its brightness and saturation. Sukhomlynsky in Pavlysh developed and implemented a clear purposeful educational system when all components (forms, methods, techniques and tools) were based on folk pedagogical and humanistic principles and had a child-centered character. The aim is in the formation of a joyful, positive attitude of the child to life. Along with traditional approaches, he used innovative authorial methods (composing fairy tales, ethical conversations, the culture of desires).

The article reveals the teacher's creative ideas about the connection of the emotional-volitional component in the formation of the personality of schoolchildren with their desire for self-education. The directions and means of actualizing the emotional-volitional conditions for the formation of a child's personality as a subject of upbringing in the heritage of Sukhomlynsky are determined. The possibility of responding the age and individual characteristics of the personality of a student who is the subject of education in a modern school is substantiated.

Key words: child's personality, emotional world, freedom, pedagogy of Vasyl Sukhomlynsky.

Постановка проблеми. Виховний вплив на особистість школяра традиційно реалізується в багатогранному виховному процесі, що органічно поєднує виховання, самовиховання і перевиховання. Виховання у новому, сучасному прочитанні $є$ не чим іншим, як створенням умов розвитку особистості через самовиховання. Вирішення цього питання спонукає до грунтовного осмислення реального стану емоційного виховання дитини, аналізу причинно-наслідкових зв'язків та грунтовного усвідомлення здобутих результатів наукового пошуку, оскільки стосується кожного і в цілому має суспільну значущість на рівні окремої особистості.

Сьогодні перед кожним учителем і батьками, особливо молодими, незалежно від соціального статусу та освіченості, постають питання щодо того, як виховувати дитину та які підходи у зв'язку з цим реалізовувати, аби вона виросла вихованою, чуйною, могла виражати свої почуття та емоції й зрештою була щасливою. Ці питання є багатогранними та вічними, як і саме виховання.

Багато науковців, дослідників, педагогів-практиків намагалися віднайти на них відповіді, однак універсального рецепта успішного емоційного виховання дитини не знайдено й досі. I це не дивно, адже немає однакових дітей і однакових батьків, як немає і однакових сімей.

У зв'язку з цим на передній план виходить педагогічна спадщина минулого, що містить відповіді на актуальні освітні питання. Такою $є$ і багатоаспектна спадщина Василя Сухомлинського, в якій, на думку вчених-сухомлиністів, окреслені шляхи «розв'язання проблем, пов'язаних із навчанням, вихованням, управлінням в умовах сьогодення.

Аналіз наукових досліджень і публікацій. Спадщина В. Сухомлинського, починаючи з періоду його діяльності, цікавила багатьох сучасників. Різні складові діяльності видатного вченого висвітлені в численних публікаціях в періодичних виданнях, в окремих монографіях, дисертаційних дослідженнях. Найбільш системно погляди педагога представлені в працях сучасних учених-сухомлиністів I. Беха, А. Богуш, В. Кузя, М. Пентилюк, О. Петренко, Г. Пустовіта, О. Савченко, О. Сухомлинської, В. Федяєвої та ін. Можливості творчого використання досвіду видатного педагога у практиці сучасних закладів освіти проаналізовані у наукових розвідках Л. Головко, Л. Заліток, О. Петренко та ін. Гуманістичні засади теорії та практики виховання й навчання в педагогічній системі В. Сухомлинського досліджували М. Антонець, Л. Бондар, В. Кузь, Л. Копієвська, О. Лавроненко та ін.

3'являються й активно поширюються нові підходи до досліджень сухомлиністики в контексті всесвітнього та європейського освітнього середовища (Сараєва, 2007).

Аналіз тематики окреслених вище досліджень свідчить, що Василь Олександрович створив оригінальну виховну систему, яка виявилася життедайною і сьогодні, оскільки у своїй основі орієнтується на Людину як найвищу цінність.

Мета статті полягає у вивченні підходів до вирішення проблеми формування емоційного світу дитини на основі аналізу педагогічної творчості Василя Сухомлинського.

Виклад основного матеріалу дослідження. Вивчення творчості В. Сухомлинського свідчить, що ключове місце у його педагогічній спадщині присвячено насамперед дитині - активній та самостійній особистості. «Людина, яка приходить до нас в школу малюком - нетяма, не повинна бути учнем у вузькому розумінні цього слова. Якщо учень для педагога тільки істота, якій треба дати, вкласти в його голову знання, - він не стане всебічно розвиненою особистістю. Особистість немислима, якщо людина не заявляє про себе, якщо в якійсь сфері духу людського вона не стала володарем, якщо не стверджує себе в діяльності й - це дуже важливо в успіхах - якщо вона не переживає за свою гідність творця, якщо вона не йде з гордо піднятою головою» (Сухомлинський, 1979, с. 81).

Призначення та виховний ідеал школи В. Сухомлинський вбачав у вихованні всебічно і гармонійно розвиненої особистості. Ця ідея отримала свій розвиток і практичне застосування у діяльності Павлиської середньої школи, яку Василь Олександрович очолював понад 30 років.

Передусім необхідно навчити дитину мислити, орієнтуватися в житті в суспільстві, вміти висловлювати свою думку. Тому в Павлиській школі вчителі початкових класів починали працювати 3 дошкільниками за два роки до вступу їх до школи. Заняття проводилися у різних формах, серед яких переважали ігри, спільна колективна праця, екскурсії в природу, щоб діти навчалися «думати про свої думки». 
Неабиякого значення надавалося також виробленню у дітей таких умінь, як «спостереження, мислення, висловлювання своєї думки, читання, писання, думаючи читати і читаючи думати» (Сухомлинський, 1979, с. 107), оволодіння якими сприяло активному сприйняттю знань та їхньому творчому застосуванню. Діти на уроках виконували творчі письмові роботи: ставили казки, писали твори про працю, природу тощо, адже саме в праці дитина переживає різні емоції, що сприяє «формуванню поглядів, переконань, прагнень, бажань, оцінки та самооцінки» (Сухомлинський, 1979, с. 217). У вирішенні цього завдання головну роль В. Сухомлинський відводив активності самої особистості, а не зовнішнім виховним впливам. Активність особистості являла собою вирішальну умову саморозвитку, самовиховання, самовдосконалення. За цих обставин рух до самовдосконалення повинен тривати все життя і включати в себе моральне, розумове, творче, трудове, естетичне, емоційне, фізичне вдосконалення.

Виховання емоцій школярів починається 3 виховання правильного ставлення до праці. Стосовно навчальної діяльності правильне ставлення - це передусім усвідомлення неподільного розуміння повноцінних знань і умінь, оцінка власних досягнень і невдач у навчанні з точки зору суспільних норм і вимог, що пред'являються до школярів. Як свідчить практика, ще до початку навчання поряд з усвідомленням існує й емоційне прийняття таких норм у формі емоційного передбачення. Саме завдяки цьому навчання стає привабливим.

Стійка невдача, якщо вона до того ж «підкріплена» постійним страхом покарання, перешкоджає прийняттю певного виду діяльності, позбавляє дитину можливості досягти успіху в чомусь іншому. Завдяки цьому може з'явитися відраза як до навчання, так і до іншого виду діяльності.

Через працю відбувається трансформація знайомого в емоційно прийняте. Тільки здобуте працею стає істинно прийнятим і спонукає до подальшої діяльності. Саме школа, де дитина вперше зустрічається 3 необхідністю постійно працювати, зобов'язана виховати працьовитість.

У дошкільному віці праця зосереджується в дитячій творчості - «поетичному слові»: дітей вчили слухати і складати казки, розповіді, вірші. В. Сухомлинський вважав це школою «емоційного життя», в якій діти осягають мову почуттів, розвивають емоційну пам'ять, вчаться співчувати та співпереживати, формують естетичні смаки. Школа за роки навчання повинна «навчити дитину бачити в красі навколишнього світу, в красі людських відносин духовне благородство, доброту, сердечність, і на цій основі стверджувати прекрасне в самому собі» (Сухомлинський, 1979, с. 187).

У Павлиській школі різні види праці були адаптовані до освітніх завдань, що відповідали природі дитини в прагненні до зміни, можливості творчих починань дітей. Для цього робочі кімнати, майстерні, лабораторії, кабінети, теплиці були спеціально обладнані не тільки простими, а й складними машинами, механізмами, обладнанням. Педагогічний колектив працював над вихованням в учнів здатності соромитися свого неробства, ліні та недбалості, а також над культивуванням у вихованців «почуття честі, порядності, поваги до самого себе» (Сухомлинський, 1979, с. 182).

Основну мету формування емоційного світу вихованців педагог вбачав у створенні радісного, позитивного ставлення до життя. Це не виключає, а навпаки, передбачає виховання у них адекватних негативно емоційних відгуків на події, що не заслуговують схвалення тобто варто вчити дітей не тільки радіти, а й засмучуватися, засуджувати, обурюватися, ненавидіти. Таким чином, потрібно навчити зростаючу особистість не тільки співчувати чужим бідам, засмучуватися, зневажати, а й виростити ії оптимістом і життєрадісною особистістю. Таке завдання вимагає від учителя неабиякої майстерності.

Завдяки волі дитина за власною ініціативою здатна виконувати дії в заздалегідь запланованому напрямку і із заздалегідь передбаченими зусиллями. Зусиллям волі можна стримати зовнішній прояв емоцій або показати абсолютно протилежні емоції.

В. Сухомлинський був переконаний, що без почуттів та волі благородний учинок - неможливий. Він вибудував для школярів органічну систему морального виховання, де особлива роль відводилася етичним бесідам, які розкривали моральні цінності, норми, викликали різноманітні моральні почуття (обов'язку, чуйності та ін.). Моральне виховання необхідно починати з раннього дитинства, щоб до підліткового віку діти вже могли побачили результати своєї праці: плодовий сад на пустирі, колосся пшениці на землі, яка колись була неродючій тощо. У роки юності вихованці на основі моральних цінностей робили благородні вчинки, формували морально правильні погляди, позиції щодо мети і сенсу життя, обов'язку, щастя. Виховання в дітей активного обурення, презирства, огиди до зла «починається із суворої непримиренності до ліні, недбалості, неробства» (Сухомлинський, 1979, с. 155). Саме завдяки цьому у свідомості школярів з'являються думки про обов'язок, тобто дитина набуває досвіду взаємин між старшими і молодшими, між членами колективу.

Учитель повинен допомогти дитині побачити емоційне забарвлення світу навколо себе, формуючи образи, що залишаться з нею на все життя. У Павлиській середній школі дітей вчили слухати музику природи, оспівувати красу рідного краю, приносити радість батькам, стверджуючи у свідомості дитини, що «любов видобувається і осягається завдяки напруженню сили духу» (Сухомлинський, 1979, с. 147). У поняття «людська любов» у Павлиші вкладали почуття вірності, відданості, обов'язку, не забуваючи про те, що ці почуття народжуються і виховуються в праці, приносячи радість оточуючим і самому собі: «Ми досягаємо того, щоб праця набувала значної суспільної ваги і починалася в ранньому дитинстві та впродовж наступних років - у підлітковому віці й у ранній юності - та служила моральному збагаченню, становила саму сутність руху на шляху до громадянської зрілості» (Сухомлинський, 1979 , с. 156).

Уся педагогічна діяльність В. Сухомлинського була спрямована на активізацію самопізнання і самоствердження дитини: «Отроцтво і рання юність вік інтелектуального, морального самоствердження 
особистості. У цьому віці нормальний духовний розвиток школяра залежить від того, наскільки глибоко відбувається його самоствердження в усіх сферах діяльності і відносин у колективі - в інтелектуальному житті, у праці, у формуванні моральних переконань. Підліток стає справжньою людиною лише тоді, коли він навчається пильно вдивлятися не тільки у навколишній світ, коли сили його душі спрямовані на те, щоб зробити себе кращим, досконалішим (Сухомлинський, 1979 , с. 242).

Василь Олександрович зауважував, що індивідуальність дитини допомагає їй пережити щастя і горе, усвідомлювати почуття власної гідності та обов'язку перед іншими людьми, колективом та суспільством, бути відповідальними за кожен свій учинок та за свою поведінку.

Педагоги повинні бути майстерними стратегами у тонкій справі виховання емоцій, ураховувати індивідуальність кожного учня, знати не лише вікові закономірності розвитку емоцій, основні потреби кожного віку, умови розвитку кожного вихованця, а й те, що його турбує, розуміти, хто потребує схвалення, а хто - осуду. Допомагаючи школярам у самовихованні емоцій, учитель повинен пам'ятати, що самовиховання - процес усвідомлений, а самовиховання емоцій - частина великої мети загального самовиховання.

Основою самовиховання дитини є іiї «бажання бути хорошою». Спочатку ця потреба - неусвідомлене бажання дитини добре робити те, що від неї вимагають старші, зокрема добре вчитися, сумлінно виконувати свої обов'язки у школі та вдома. Дорослішаючи, потреба дитини «бути хорошою» ускладнюється і змінюється: тепер вона включає все більше якостей морального ідеалу, що виступають метою виховання і з часом трансформуються у потребу бути справжнім громадянином, виражати себе як особистість у творчій праці, утверджуючи у спілкуванні з людьми свій моральний ідеал. Саме розвиток цієї потреби визначається прагненням $\mathrm{i}$ можливостями дитини до самовиховання, до активного розвитку своїх здібностей і моральних якостей.

Таким чином, здатність дитини бути вихованою включає створення у неї позиції суб'єкта виховання, що активно сприймає моральний ідеал вихователя. «Здатність ця - чуйність душі, чуйність серця вихованця до найтоншого відтінку слова вихователя, до його погляду, до жесту, до усмішки, до задуми і мовчазності» (Сухомлинський, 1979, с. 521).

В. Сухомлинський намагався викликати в дитини оцінку своїх вчинків, в яких відображається ставлення до людей і до себе. Виховання стимулювало внутрішню роботу розуму і серця. Головне значення мали не самі по собі умови розвитку суб'єкта, а його місце в цих умовах, ставлення до них і характер діяльності в них. В основу виховання було покладено систему виховних відносин, які складалися в процесі взаємодії педагогів і вихованців, тобто суб'єктів виховання. Відносинам учителя та учня Василь Олександрович надавав особливого значення, адже вчитель, будучи так чи інакше членом учнівського колективу, одночасно $\epsilon$ прикладом суспільних відносин: він не тільки формує відносини в дитячому колективі, а й через відносини виховує, навчає, творить зростаючу особистість. І від того, якими є ці відносини, багато в чому залежить, якою вийде людина зі стін школи. Виховати людину можна тільки людяністю - це переконання Сухомлинського як директора поділяв увесь педагогічний колектив у результаті цілеспрямованої роботи. Педагоги повинні сформувати у вихованців «розвинену вразливість, емоційне реагування на ті чи інші явища навколишньої дійсності» (Сухомлинський, 1979, с. 334) як високий рівень розвитку емоційної сфери.

Видатний педагог із метою виховання в дітей почуттів майстерно використав життєві ситуації. У його книгах знаходимо приклади того, як він пробуджував в учнів співчуття, навчав надавати людям допомогу, якщо вони ії потребували. Він наголошував, що у процесі виховання емоцій варто прагнути, аби діти були щасливими і відчували радість від кожного прожитого дня, були наполегливими у подоланні труднощів, аби у їхній душі був глибокий і дієвий відгук на все, що заслуговує на співчуття або засудження.

Успіх, на думку В. Сухомлинського, - це основа, на якій грунтується справжнє виховання. Тільки успіх дитини формує у неї достатню віру в себе, у свої сили, а на цій основі з'являється бажання «бути хорошим». Кожна дитина повинна вірити у свої можливості, вчитися із захопленням, відчувати постійну турботу батьків і вчителів.

Особливе місце у творах В. Сухомлинського належить навколишньому середовищу. Так, дослідники Н. Борисенко та А. Бальоха стверджують, що в учнів Павлиської школи це середовище постійно розширювалося і збагачувалося. У кожного класного колективу був свій куточок краси: кілька кущів троянд, виноградник, персиковий сад, маленька діброва тощо (Борисенко, Бальоха, 2018). Завдяки цьому мікросередовищу педагогічний колектив учив кожну дитину «піклуватися про живе і прекрасне, бути доброю і чуйною». Кожен школяр вкладав душу у «свою» рослину, дерево, кущик; навчався дорожити речами, створеними іншими людьми. Таким чином, середовище не тільки спонукає людину до активної діяльності, а й навчає милуватися красою, оберігати створене іншими людьми, «щоб людина могла справитися з обмеженням своїх бажань» (Сухомлинський, 1979, с. 576). Зважаючи на це, педагогічним колективом Павлиської школи було розроблено спеціальну методику спільної роботи педагогічного колективу й батьків, що одержала назву «Батьківська школа», завдяки якій через «працю, науку, майстерність і творчість» (Сухомлинський, 1979, с. 574) розкривалася батьківська педагогіка, адже саме в родині закладаються основи здатності відчувати інших людей та вміння жити серед людей.

Подальша робота тривала в школі. Учителі розуміли, що в центрі їхньої праці - не лише дитина, а також «... найтонші сфери духовного життя особистості, яка формується, - розум, почуття, воля, переконаність, самосвідомість» (Сухомлинський, 1979, с. 450). Починаючи з молодшого шкільного віку, завдання педагогів полягало в необхідності доводити до свідомості дітей привабливість та соціальну значимість таких емоційно насичених особистісних якостей, як: чуйність, доброта, любов до праці, уміння співпереживати, оптимізм, життєрадісність, емоційна стійкість тощо. Вчителі 
мали донести до усвідомлення дітьми життєвої важливості стриманості, самовладання, які безпосередньо пов'язані з умінням управляти своїми емоціями. Вплив педагогів на самовиховання змістовних емоційних рис означає, по суті, участь у формуванні в дітей внутрішніх моральних інстанцій, тобто доведення того, що вони є частиною морального виховання, спрямованого на виховання всебічно розвиненої особистості.

До основних моральних почуттів В. Сухомлинський відносить почуття совісті, сорому, відповідальності та обов'язку. Совість визначається ним як «почуття, помножене на свідомість», «знання, багаторазово помножене на переживання і відчуття», «емоційний страж переконань» (Сухомлинський, 1979, с. 279). Це моральне почуття не тільки виникає на основі особистого емоційного ставлення з позицій моралі до різних явищ навколишньої дійсності, а й регулює поведінку людини. Щодо почуття обов'язку, то воно обумовлює розвиток совісті, почуття відповідальності та сорому й трактується В. Сухомлинським як усвідомлення переживання особистістю своєї відповідальності перед Вітчизною, суспільством, як прояв совісті, що виражається в особистому ставленні до людей, предметів і явищ навколишнього світу і до самого себе, як вище досягнення єдності моральних переконань і діяльності, як результат значного морального досвіду та передумова його збагачення.

Василем Олександровичем також було обгрунтовано й уведено в педагогічний обіг поняття «повинність», що тлумачиться як найважливіший осередок педагогічних зусиль і ключова ідея морального виховання. Справжня майстерність виховання, вважав педагог із Павлиша, полягає не тільки в розвитку в дитини почуття обов'язку, щоб вона сама віддавала собі накази, безкорисливо, без похвали творила добро та відчувала від цього радість, а й у розвитку іiі совісті, щоб завдяки їй вона відчувала набагато більшу відповідальність, ніж перед будь-якими зовнішніми факторами. Усе, що В. Сухомлинський вважав основоположним у вихованні дитини, тобто вміння поєднувати і підпорядковувати особисті інтереси суспільним, прагнення до морального вдосконалення, - все це залежало від розвитку почуття обов'язку.

Почуття відповідальності людини перед суспільством, іншими людьми, а також перед самим собою, перед власною совістю трактувалося ним у тісному зв'язку і взаємозумовленості з почуттям сорому. У зв'язку з цим В. Сухомлинський писав: «Сором - повітря, на якому тримаються крила людської відповідальності. Відчуваючи відповідальність, людина боїться здаватися поганим. Переживаючи почуття сорому, людина робить крок уперед на шляху свого морального розвитку» (Сухомлинський, 1979, с. 283). Розвиток цих почуттів сприяє розвитку інших складових емоційної сфери особистості, як-от: патріотизму, громадянськості, співпереживання, співчуття, честі, гордості, гідності, самоповаги.

Засобами виховання емоційної сфери дитини у В. Сухомлинського стають природа рідного краю, досягнення та історія країни, вчинки видатних людей, суспільне життя класу та школи.

Отже, у процесі виховання емоцій слід прагнути, щоб школярі були щасливими, відчували радість від кожного прожитого дня. У них слід виховувати стійкість до труднощів, глибокий і дієвий відгук на все, що заслуговує на співчуття чи засудження.

Найважливішою складовою емоційно-вольової виховання в Павлиській середній школі $є$ культура бажань - «одне із джерел людяності, щирості (тобто гуманних почуттів), внутрішньої самодисципліни» (Сухомлинський, 1979, с. 92). Вона стає внутрішнім стимулом поведінки людини, завдяки чому особистість відкидає аморальні бажання, які є мотивами її поведінки. Формування культури бажань, самообмеження, відчування понять «можна», «не можна», «треба»одна $з$ практичних цілей розвитку моральних почуттів, що ініціюють вольовий акт особистості щодо вибору морально-ціннісних учинків і поведінки. У процесі педагогічної взаємодії індивідуальний підхід до розвитку почуттів і волі особистості вихованця реалізується як двосторонній процес, ціннісний для дитини і педагога, орієнтований на оптимальний розвиток особистості як індивідуальності.

На глибоке переконання Василя Олександровича, розвиток особистості як індивідуальності неможливий без розвитку емоційно-вольової культури як внутрішнього регулятора і мотивів її поведінки. Оскільки розвиток емоційно-вольової культури - це процес внутрішній, індивідуально-особистісний, то неабияке значення для його ефективності набуває самостійна активність особистості. Зважаючи на це, питання самовиховання особистості займає одне 3 ключових місць у педагогічній системі В. Сухомлинського. Він неодноразово підкреслював, що тільки «виховання, яке спонукає до самовиховання, і $є$ справжнім вихованням» (Сухомлинський, 1979, с. 244).

Висновки. Отже, зважаючи на викладене вище, зауважимо, що В. Сухомлинський у Павлишській школі розробив чітку цілеспрямовану освітню систему, основним із завдань якої, поряд з іншими, було формування емоційного світу дитини, на створення якого впливає чимало сил: «... по-перше, сім'я, а в сім'ї найтонший і наймудріший скульптор - мати; по-друге, особа педагога $з$ усіма його духовними багатствами і цінностями, з його мудрістю, знаннями, уміннями, захопленнями, життєвим досвідом, інтелектуальними, естетичними, творчими потребами, інтересами, прагненнями; по-третє, колектив (дитячий, підлітковий, юнацький) з усією його могутньою силою виховного впливу на кожну особу; по-четверте, сама особа вихованця, його самовиховання; по-п’яте, духовне життя вихованця в світі інтелектуальних, естетичних і моральних цінностей - я маю на увазі передусім книжку; по-шосте, зовсім непередбачені скульптори (підліток, 3 яким вихованець подружився на вулиці; родич чи близький знайомий, який приїхав на тиждень у гості й полонив маленьку людину радіотехнікою чи мріями про зоряні світи)» (Сухомлинський, 1979, с. 568). Усі форми, методи, прийоми та засоби, реалізовані в означеній вище системі, грунтувалися на народно-педагогічних і гуманістичних засадах, а також мали дитиноцентричний характер.

Перспективи подальших досліджень передбачають вивчення питань дидактики В. Сухомлинського 
як цілісної системи, розгляд літературної спадщини педагога-новатора як невід'ємної складової його педагогічної системи, а також дослідження наукових праць зарубіжних учених про систему видатного педагога.

\section{СПИСОК ВИКОРИСТАНОЇ ЛІТЕРАТУРИ}

Сараєва, О. В. (2007). Педагогічна система В. О. Сухомлинського в науковому доробку вітчизняних учених: автореф. дисертації ... канд. пед. наук: 13.00.01. Київ: Інститут педагогіки АПН України. 21 с.

Сухомлинський, В. О. (1979). Проблеми виховання всебічно розвиненої особистості. Вибрані твори: в 5 т. Київ: Радянська школа. Т. 1. С. 57-218.

Сухомлинський, В. О. (1979). Духовний світ школяра. Вибрані твори: в 5 т. Київ: Радянська школа. T. 1. C. $219-424$.

Сухомлинський, В. О. (1979). Методика виховання колективу. Вибрані твори: в 5 т. Київ: Радянська школа. Т. 1. С. 425-668.

Борисенко, Н. М., Бальоха, А. С. (2018) Використання педагогічної спадщини В. Сухомлинського на уроках природознавства в контексті Нової української школи. Педагогічний альманах. Вип. 38. С. 22-28.

Сухомлинський, В. О. (1979). Формування комуністичних переконань молодого покоління Вибрані твори: в 5 т. Київ: Радянська школа. Т. 2. С. 5-155.

Сухомлинський, В. О. (1979). Серце віддаю дітям. Вибрані твори: в 5 т. Київ: Радянська школа. Т. 3. C. 5-297.

Сухомлинський, В. О. (1979). Народження громадянина. Вибрані твори: в 5 т. Київ: Радянська школа. T. 3. C. 299-628.

Сухомлинський, В. О. (1979). Павлишська середня школа. Вибрані твори: в 5 т. Київ: Радянська школа. T. 4. C. 5-410.

Сухомлинська, О. В. (2012). Деякі аспекти еволюції сприйняття творчості В. Сухомлинського: дорога довжиною в 40 років. Історико-педагогічний альманах. Вип. 1. С. 62-72 URL: http://nbuv.gov.ua/UJRN/ Ipa_2012_1_14 (дата звернення: 10.09.2021).

\section{REFERENCES}

Saraieva, O. V. (2007). Pedahohichna systema V. O. Sukhomlynskoho v naukovomu dorobku vitchyznianykh uchenykh [Pedagogical system of Vasyl Sukhomlynsky in the science achievements of domestic scientists]: avtoref. dysertatsii ... kand. ped. nauk: 13.00.01. Kyiv: Instytut pedahohiky APN Ukrainy. $21 \mathrm{~s}$. [in Ukrainian].

Sukhomlynskyi, V. O. (1979). Problemy vykhovannia vsebichno rozvynenoi osobystosti [Problems of education of a comprehensively developed personality]. Vybrani tvory: v 5 t. Kyiv: Radianska shkola. T. 1. S. 57-218. [in Ukrainian].

Sukhomlynskyi, V. O. (1979). Dukhovnyi svit shkoliara [Student spiritual world]. Vybrani tvory: v 5 t. Kyiv: Radianska shkola. T. 1. S. 219-424. [in Ukrainian].

Sukhomlynskyi, V. O. (1979). Metodyka vykhovannia kolektyvu [Methods of team education]. Vybrani tvory: $\mathrm{v} 5 \mathrm{t}$. Kyiv: Radianska shkola. T. 1. S. 425-668. [in Ukrainian].

Borysenko, N. M., Balokha, A. S. (2018) Vykorystannia pedahohichnoi spadshchyny V. Sukhomlynskoho na urokakh pryrodoznavstva $\mathrm{v}$ konteksti Novoi ukrainskoi shkoly [Using of pedagogical heritage of Vasyl Sukhomlynsky in science lessons in the context of the New Ukrainian School]. Pedahohichnyi almanakh. Vyp. 38. S. 22-28. [in Ukrainian].

Sukhomlynskyi, V. O. (1979). Formuvannia komunistychnykh perekonan molodoho pokolinnia. Vybrani tvory: v 5 t. Kyiv: Radianska shkola. T. 2. S. 5-155. [in Ukrainian].

Sukhomlynskyi, V. O. (1979). Sertse viddaiu ditiam [I give my heart to children]. Vybrani tvory: v 5 t. Kyiv: Radianska shkola. T. 3. S. 5-297. [in Ukrainian].

Sukhomlynskyi, V. O. (1979). Narodzhennia hromadianyna [Birth of a citizen]. Vybrani tvory: v 5 t. Kyiv: Radianska shkola. T. 3. S. 299-628. [in Ukrainian].

Sukhomlynskyi, V. O. (1979). Pavlyshska serednia shkola [Pavlysh secondary school]. Vybrani tvory: v 5 t. Kyiv: Radianska shkola. T. 4. S. 5-410. [in Ukrainian].

Sukhomlynska, O. V. (2012). Deiaki aspekty evoliutsii spryiniattia tvorchosti V. Sukhomlynskoho: doroha dovzhynoiu v 40 rokiv [Some aspects of the evolution of creativity Vasyl Sukhomlynsky: a road 40 years long]. Istoryko-pedahohichnyi almanakh. Vyp. 1. S. 62-72 URL: http://nbuv.gov.ua/UJRN/Ipa_2012_1_14 (data zvernennia: 10.09.2021). [in Ukrainian].

Дата надходження до редакиіï: 11.10.2021 p. 